\title{
Effect of methionine on the metabolic fate of liver folates in vitamin $B_{12}$-deficient rats
}

\author{
BY MARGARETHA J ÄGERSTAD, B. ÁKESSON \\ AND C. FEHLING \\ Dalby Community Health Research Centre, \\ Department of Physiological Chemistry and Department of Neurology, \\ University of Lund, Lund, Sweden
}

(Received 7 December 1979 - Accepted 10 June 1980)

\begin{abstract}
I. Hepatocytes isolated from vitamin $\mathbf{B}_{19}$-deficient and vitamin $\mathbf{B}_{12}$-supplemented rats were maintained in primary culture and were used to study the effect of methionine on the metabolism of [ $\left.{ }^{2} \mathrm{H}\right]$ folic acid and [5-" ${ }^{14}$ C]methyltetrahydrofolic acid.
\end{abstract}

2. Vitamin $B_{12}$ levels were reduced by approximately $75 \%$ in the hepatocytes from the deficient animals. Total folate and methyltetrahydrofolic acid concentrations were also significantly reduced.

3. There was no significant difference in the uptake and retention of added $\left[{ }^{2} \mathrm{H}\right]$ folic acid and $\left[5^{-14} \mathrm{C}\right]-$ methyltetrahydrofolic acid between the hepatocytes of the two groups. The incorporation of ${ }^{14} \mathrm{C}$ into phospholipids was reduced by approximately $60 \%$ in the vitamin $\mathbf{B}_{12}$-deficient hepatocytes $(P<0.001)$.

4. The addition of methionine to the culture medium doubled the uptake and retention of ${ }^{8} \mathrm{H}$ in both groups, but it did not change the amount of water-soluble ${ }^{14} \mathrm{C}$ compounds. In the vitamin $\mathrm{B}_{12}$-deficient hepatocytes mainly methylated folate increased, whereas non-methylated folate increased in the hepatocytes of the control animals. A tenfold increase of ${ }^{14} \mathrm{C}$ incorporated into phospholipids was found in both groups after methionine was added.

5. Demethylation of methyltetrahydrofolic acid, the intracellular retention of folate and the utilization of liberated methyl groups, for example in the methylation of phospholipids, were highest in the presence of both methionine and vitamin $B_{13}$ suggesting an intimate co-ordination between these two substances in the regulation of folate metabolism.

The metabolic relationship between folate, vitamin $B_{12}$ and methionine has been a subject of several investigations and reviews in recent years (Vidal \& Stokstad, 1974; Herbert \& Das, 1976; Krebs et al. 1976). Both vitamins are required as cofactors in the biosynthesis of methionine from homocysteine (Fig. I). The methyl group in methyltetrahydrofolic acid is transferred via vitamin $B_{12}$ and tetrahydropteroylglutamate methyltransferase ( $E C$ 2. I I . 13) to homocysteine. Methyltetrahydrofolic acid is produced from 5,10-methylenetetrahydrofolic acid by an irreversible reaction, and the methylation of homocysteine is the only known way in which methyltetrahydrofolic acid may lose its methyl group (Katzen \& Buchanan, 1965).

In vitamin $B_{12}$ deficiency, the methyltransferase activity is depressed; and owing to the irreversibility of the reaction forming methyltetrahydrofolic acid, this compound accumulates. Consequently, much of the available folate becomes trapped and unavailable (Herbert \& Zalusky, 1961, 1962; Noronha \& Silverman, 1962).

In the presence of methionine, the formation of methyltetrahydrofolic acid is depressed, whereas without methionine and vitamin $\mathbf{B}_{\mathbf{1 2}}$ methyltetrahydrofolic acid is trapped owing to a lack of inhibition of its synthesis by S-adenosylmethionine. Thus, methionine is a key factor in the regulation of the methyltetrahydrofolic acid concentration (Chiao \& Stokstad, 1977).

It has also been reported that vitamin $\mathrm{B}_{12}$ affects the cellular uptake of methyltetrahydrofolic acid (Lavoie et al. 1974) and is involved in the intracellular synthesis of pteroylpolyglutamates (Chanarin et al. 1974).

The present investigation was designed to illustrate the interdependence of vitamin $B_{18}$, 


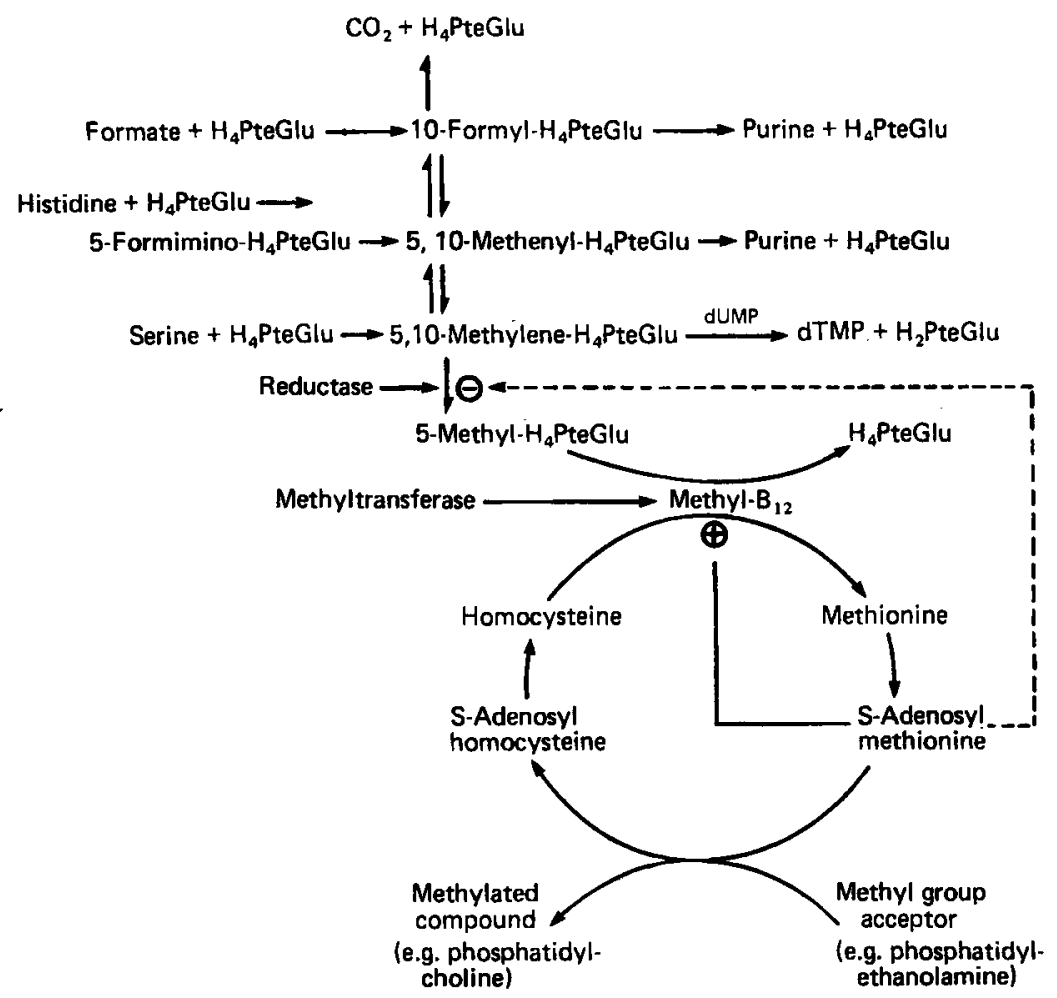

Fig. I. Metabolic scheme showing the pathway for transfer of one carbon unit by folate derivatives with the involvement of vitamin $\mathrm{B}_{12}$ and methionine. (Glu, glutamic acid; PteGlu, pteroylglutamic acid; $\mathrm{H}_{4}$, tetrahydro; $\mathrm{H}_{2}$, dihydro; dUMP, deoxyuridylate; dTMP; deoxythymidylate.)

folate and methionine at the cellular level by using cultured hepatocytes from vitamin $B_{12}$-deficient rats. The results obtained are discussed in relation to similar studies performed in vivo.

\section{EXPERIMENTAL PROCEDURES}

\section{Animals}

Wistar strain, male rats were placed on a vitamin $B_{12}$-deficient diet from 4 weeks of age, and the experiments were performed on 13-month-old animals. The control animals were supplemented with vitamin $B_{12}$ in the drinking-water $(20 \mu \mathrm{g} / 1)$. The rats were housed in stainless-steel cages with elevated wire-mesh floors as described by Fehling et al. (1978).

\section{Diet}

The diet has been described previously (Fehling et al. 1978). Its gross composition was (g/kg diet): sugars 330 , soya-bean protein $57 \mathrm{I}$, soya-bean oil 48 , vitamin and salt mixtures 55. It also contained $(/ \mathrm{kg}) 5.5 \mathrm{~g}$ L-methionine, I $\mathrm{mg}$ folic acid and less than $2 \mu \mathrm{g}$ vitamin $\mathrm{B}_{12}$.

\section{Isotopes}

$\left[5^{-14} \mathrm{C}\right]$ methyltetrahydrofolic acid, barium salt $(58 \mathrm{mCi} / \mathrm{mmol}), 3^{\prime}, 5^{\prime}, 9^{\prime}\left[{ }^{3} \mathrm{H}\right]$ folic acid, potassium salt $(500 \mathrm{mCi} / \mathrm{mmol})$ and $\left[{ }^{3} \mathrm{H}\right]$ ethanolamine $(3.8 \mathrm{Ci} / \mathrm{mmol})$ were obtained from The Radiochemical Centre, Amersham, Bucks, UK. 


\section{In vivo experiments}

Vitamin $\mathrm{B}_{12}$-deficient rats and control rats were injected intraperitoneally with $70 \mu \mathrm{Ci}\left[{ }^{3} \mathrm{H}\right]-$ ethanolamine and I mmol L-methionine/ $\mathrm{kg}$ body-weight $4 \mathrm{~h}$ before slaughter. The rats were fasted for $24 \mathrm{~h}$ before death.

\section{Preparation of hepatocytes}

After the control and vitamin $\mathbf{B}_{\mathbf{1 2}}$-deficient rats had fasted overnight, hepatocytes were prepared as previously described ( $\AA$ kesson, 1977). The hepatocytes were transferred in $2.5 \mathrm{ml}$ medium to $60 \mathrm{~mm}$ plastic petri dishes coated with collagen (Lin \& Snodgrass, 1975). The medium used was L-is tissue-culture medium lacking methionine, choline, inositol and folic acid and supplemented with $28 \mathrm{~mm}$-Hepes (N-2-hydroxyethylpiperazine-N'-2ethane sulphonic acid), I-mM-sodium succinate, insulin $(0.5 \mu \mathrm{g} / \mathrm{ml})$, penicillin $(100 \mu \mathrm{g} / \mathrm{ml})$, gentamycin $(50 \mu \mathrm{g} / \mathrm{ml})$ and foetal calf serum (20 g/1) (Âkesson, I977). After I h the medium in the petri dishes was changed to the same medium but with the addition of $\left[{ }^{3} \mathrm{H}\right]$ folic acid $(2 \mu \mathrm{Ci}, 2 \mu \mathrm{g}),\left[5^{-14} \mathrm{C}\right]$ methyltetrahydrofolic acid $(0.5 \mu \mathrm{Ci}, 5 \cdot 7 \mu \mathrm{g})$ or methionine $(0.5 \mathrm{mM})$, or both.

After $20 \mathrm{~h}$ the medium was removed and the hepatocytes were washed with $2 \times 1 \mathrm{ml}$ ice-cold isotonic sodium chloride $(9 \mathrm{NaCl} / 1)$. The cells were transferred with $3 \times \mathrm{Iml}$ 0.1 M-sodium phosphate buffer, $\mathrm{pH} 6 . \mathrm{I}$, containing freshly added ascorbic acid (I50 mg/ $100 \mathrm{ml}$ buffer), into tubes, which were stored at $-20^{\circ}$ until assay.

\section{Analytical procedures}

Folate was liberated from the harvested hepatocytes by boiling them for Io $\min$ in $0.1 \mathrm{M}$ sodium phosphate buffer, pH 6.I, containing freshly added ascorbic acid (I50 mg/100 ml buffer). Folate concentration and radioactivity were determined in the supernatant fraction after centrifugation. Lipids were extracted from the pellet as described previously ( $\AA$ kesson, 1977). Lipids from whole livers were extracted and separated by thin-layer chromatography (Åkesson et al. 1979). The phospholipid was regarded as representing the amount of hepatocytes present in each culture.

Methods for microbiological analyses of folates and vitamin $B_{12}$ have been described earlier (Fehling \& Jägerstad, I978).

\section{RESULTS}

\section{Experiments in cultured hepatocytes}

Effect of vitamin $B_{12}$ status on folate metabolism. The hepatocytes obtained from vitamin $B_{12}$-deficient rats contained 0.02-0.04 nmol of vitamin $B_{12}$ per $\mu \mathrm{mol} P(P=$ lipid phosphorus as a measure of cellular mass). The corresponding value for the control hepatocytes was $0.15-0.19 \mathrm{nmol}$ per $\mu \mathrm{mol} P$. The deficient hepatocytes contained lower concentrations of total folates and methylated tetrahydrofolates, although the proportion of methylated tetrahydrofolates was not significantly different (Table 1 ).

To investigate the influence of vitamin $\mathrm{B}_{12}$ status on the incorporation of folates, $\left[{ }^{3} \mathrm{H}\right]$ folic acid and $\left[5^{-14} \mathrm{C}\right]$ methyltetrahydrofolic acid were added to the culture medium separately or in combination. No difference between the groups could be demonstrated regarding the uptake of ${ }^{3} \mathrm{H}$ radioactivity and ${ }^{14} \mathrm{C}$ radioactivity after incubation for $20 \mathrm{~h}$ (Table 2 ). The added folates retained in the cells accounted for approximately half the total folate in deficient hepatocytes and a quarter to a half in the controls (Table I).

Addition of $\left[5^{-14} \mathrm{C}\right]$ methyltetrahydrofolic acid increased total folate and methylated folates in both groups $(P<0.001)$. The proportion of methylated folate rose from 52 to $7 \mathrm{r} \%$ in the vitamin $\mathrm{B}_{12}$-deficient and from 70 to $79 \%$ in the vitamin $\mathbf{B}_{12}$-supplemented group (Table I). 
364 Margaretha Jägerstad, B. Åkesson and C. Fehling

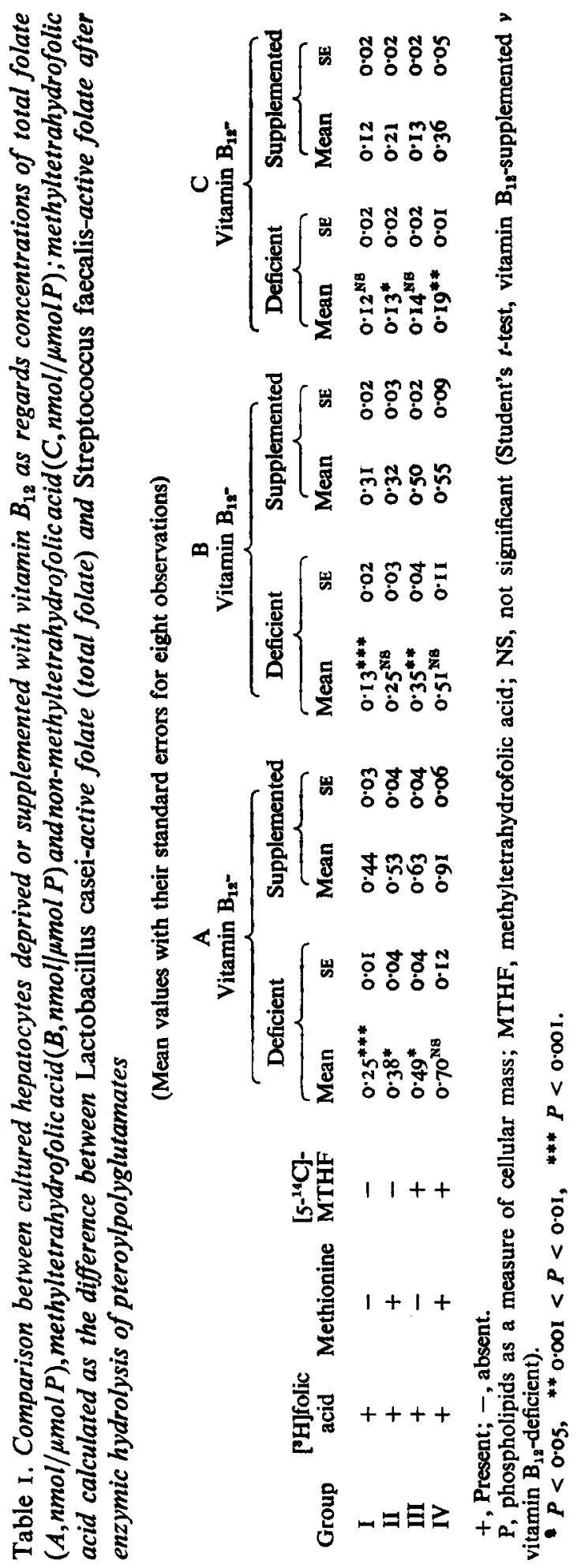


Table 2. The uptake and retention of $\left[{ }^{3} \mathrm{H}\right]$ activity from $\left[{ }^{3} \mathrm{H}\right]$ folic acid and $\left[{ }^{4} \mathrm{C}\right]$ activity from $\left[5^{-14} C\right] M T H F$ (percentage of administered dose/umol phospholipids $(P)$ in hepatocytes cultured with and without methionine and the folate isotopes for $20 \mathrm{~h}$

(Mean values with their standard errors for eight observations)

\begin{tabular}{|c|c|c|c|c|c|c|c|c|c|c|}
\hline \multirow{3}{*}{$\begin{array}{l}{\left[{ }^{3} \mathrm{H}\right]-} \\
\text { folic } \\
\text { acid }\end{array}$} & \multirow{3}{*}{$\begin{array}{l}\text { Methio- } \\
\text { nine }\end{array}$} & \multirow{3}{*}{$\begin{array}{l}{\left[5^{-14} \mathrm{C}\right]-} \\
\text { MTHF }\end{array}$} & \multicolumn{4}{|c|}{$\left[{ }^{[} \mathrm{H}\right]$ activity } & \multicolumn{4}{|c|}{$\left[{ }^{14} \mathrm{C}\right]$ activity } \\
\hline & & & \multicolumn{2}{|c|}{$B_{12}$-deficient } & \multicolumn{2}{|c|}{$\mathbf{B}_{12}$-supplemented } & \multicolumn{2}{|c|}{$\mathrm{B}_{12}$-deficient } & \multicolumn{2}{|c|}{$\mathrm{B}_{1 \mathbf{1}}$-supplemente } \\
\hline & & & Mean & SE & Mean & SE & Mean & $\mathrm{SE}$ & Mean & SE \\
\hline+ & $\bar{t}$ & - & $2.52^{\mathrm{Ng}}$ & 0.09 & 2.62 & 0.14 & 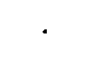 & $\cdot$ & $\cdot$ & $\dot{.}$ \\
\hline+ & - & + & $\begin{array}{l}4.40^{\mathrm{Nos}} \\
2.63^{\mathrm{Ng}}\end{array}$ & 0.25 & $2 \cdot 82$ & 0.20 & $2 \cdot 22^{\mathrm{NB}}$ & $0 \cdot 16$ & $2 \cdot 60$ & 0.45 \\
\hline+ & + & + & $3.79^{\mathrm{Ng}}$ & 0.29 & $4 \cdot 38$ & $0.4 \mathrm{I}$ & $2 \cdot 57^{\mathrm{NB}}$ & 0.25 & $3 \cdot 65$ & 0.69 \\
\hline
\end{tabular}

+ , Present; - absent.

MTHF, methyltetrahydrofolic acid; P, phospholipids as a measure of cellular mass; NS, not significant (Student's $t$-test, different from $B_{12}$-supplemented rats).

Table 3. Effect of methionine on methylation of phospholipids $(P$; as a measure of cellular mass) from $\left[5^{-14} \mathrm{C}\right]$ methyltetrahydrofolic acid in cultured hepatocytes from rats deprived of or supplemented with vitamin $B_{12}$

(Mean values with their standard errors for eight observations; [14C] activity is expressed as a percentage of administered doses $/ \mu \mathrm{mol} P ; P=$ lipid phosphorus which was used as a measure of cellular mass)

\begin{tabular}{|c|c|c|c|c|}
\hline & \multicolumn{2}{|c|}{ Vitamin $\mathbf{B}_{12}$-deficient } & \multicolumn{2}{|c|}{ Vitamin $\mathbf{B}_{\mathbf{1 2}}$-supplemented } \\
\hline & Mean & SE & Mean & SE \\
\hline With methionine & $0 \cdot 7^{* * * *}$ & 0.24 & $1 \cdot 72^{* * * *}$ & 0.49 \\
\hline Without methionine & 0.06 & 0.02 & 0.16 & 0.05 \\
\hline
\end{tabular}

The incorporation of ${ }^{14} \mathrm{C}$ from $\left[5^{-14} \mathrm{C}\right]$ methyltetrahydrofolic acid into lipids was significantly lower $(P<0.00 \mathrm{I})$ in the vitamin $\mathrm{B}_{12}$-deficient hepatocytes (Table 3$)$. The radioactivity was found almost exclusively in phosphatidylcholine $(8 \mathrm{I}-93 \%)$, indicating that it was incorporated by phospholipid methylation.

Effect of methionine. When methionine was added to the culture medium the metabolism of ${ }^{3} \mathrm{H}$ folate was affected in several respects (Table $\mathrm{I}$, group II versus group I). The total amount of folate increased in both groups but significantly $(P<0.05)$ only in the vitamin $B_{12}$-deficient group. Furthermore, in the vitamin $B_{12}$-deficient group the methylated pool was nearly doubled $(0.00 I<P<0.01)$, whereas in the vitamin $\mathbf{B}_{12}$-supplemented group only the non-methylated folates increased to a comparable extent $(0.00 \mathrm{I}<P<0.01)$. Addition of methionine to the medium in the presence of both $\left[{ }^{3} \mathrm{H}\right]$ folic acid and $\left[5^{14} \mathrm{C}\right]-$ methyltetrahydrofolic (Table I, group IV versus group III) also increased methylated folate in the vitamin $\mathrm{B}_{12}$-deficient group (0.001 $\left.<P<0.01\right)$, whereas in the supplemented group only non-methylated folate increased significantly $(0.001<P<0.01)$. The uptake of ${ }^{3} \mathrm{H}$ from [ $\left.{ }^{3} \mathrm{H}\right]$ folic acid was nearly doubled in both groups when methionine was added to hepatocyte cultures (Table 2). The incubation period for the uptake of $\left[{ }^{3} \mathrm{H}\right]$ folic acid is shown in Fig. 2. Methionine administration caused a steady increase of ${ }^{3} \mathrm{H}$ with time in hepatocytes from both vitamin $B_{12}$-deficient and supplemented rats.

The addition of methionine did not affect the amount of cellular water-soluble ${ }^{14} \mathrm{C}$ 


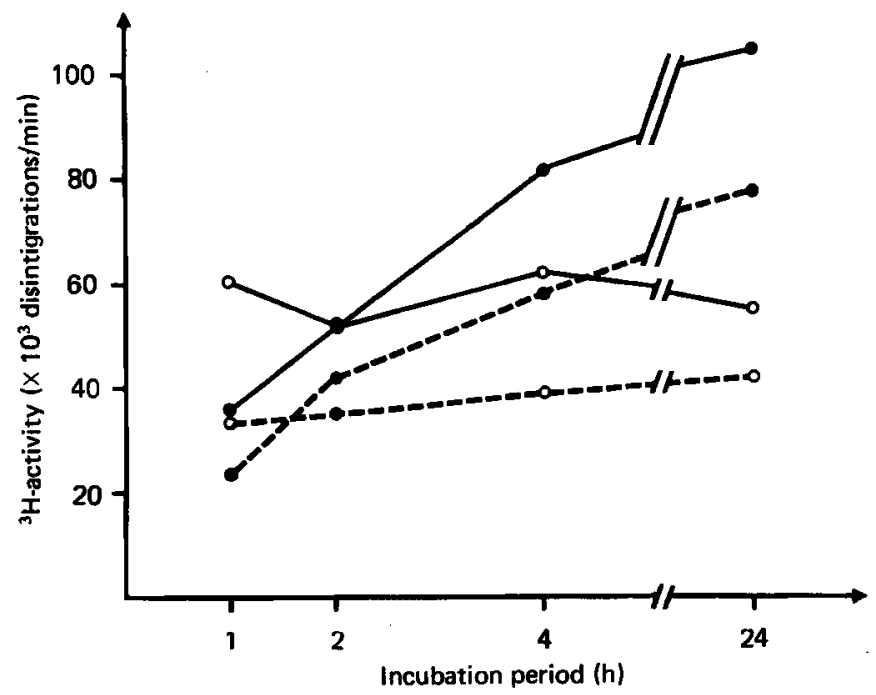

Fig. 2. Effect of methionine on the uptake and retention of $\left[{ }^{3} \mathrm{H}\right]$ folic acid in cultured hepatocytes from vitamin $B_{19}$-deficient rats and controls. Controls with methionine $(--0)$, without methionine $\left(\mathrm{O}_{-} \mathrm{O}\right)$; vitamin $\mathrm{B}_{1 \mathrm{y}}$-deficient with methionine $\left(\mathrm{O}_{---O}\right)$, without methionine $\left(\mathrm{O}_{--}-\mathrm{O}\right)$.

Table 4. Effect of methionine on phospholipid methylation in liver of rats deprived of or supplemented with vitamin $B_{12}$ determined after injection of $\left[{ }^{3} \mathrm{H}\right]$ ethanolamine

\begin{tabular}{|c|c|c|c|c|c|c|}
\hline & \multicolumn{4}{|c|}{ Vitamin $B_{12}$-deficient } & \multirow{2}{*}{\multicolumn{2}{|c|}{$\underset{\mathbf{B}_{12} \text {-supplemented }}{\text { Vitamin }}$}} \\
\hline & & & \multicolumn{2}{|c|}{ Methionine† } & & \\
\hline & Mean & SE & Mean & SE & Mean & SE \\
\hline $\begin{array}{l}\text { Liver uptake of }\left[{ }^{3} \mathrm{H}\right] \text { ethanolamine } \\
\text { injected intraperitoneally } \\
\left(\times 10^{-2} / \mathrm{g} \text { wet tissue }\right)\end{array}$ & $174^{* * *}$ & 22 & $241^{*}$ & 27 & 331 & 13 \\
\hline $\begin{array}{l}{ }^{3} \mathrm{H} \text { in phosphatidylcholine }(\%) \ddagger \\
\text { No. of rats }\end{array}$ & $\begin{array}{r}12 \\
5\end{array}$ & $1 \cdot 4$ & $\begin{array}{l}14 \cdot 5^{* * *} \\
4\end{array}$ & 0.8 & $\frac{19 \cdot 9}{6}$ & 0.7 \\
\hline
\end{tabular}

compounds after incubation with $\left[5^{-14} \mathrm{C}\right]$ methyltetrahydrofolic acid (Table 2), but increased the incorporation of ${ }^{14} \mathrm{C}$ into phospholipids tenfold in both groups regardless of vitamin $B_{12}$ status (Table 3).

\section{Experiments in vivo}

The vitamin $B_{12}$-deficient rats weighed less than the control rats, and their plasma levels of vitamin $B_{12}$ were approximately $57 \mathrm{pmol} / 1$ versus $916 \mathrm{pmol} / 1$ in the control rats. Corresponding figures for the liver vitamin $B_{12}$ were I I nmol/g versus $79 \mathrm{nmol} / \mathrm{g}$.

The effect of methionine on phospholipid methylation was studied after injection of $\left[{ }^{3} \mathrm{H}\right]$ ethanolamine. The uptake of $\left[{ }^{3} \mathrm{H}\right]$ ethanolamine into liver phospholipids was significantly lower in vitamin $B_{12}$-deficient rats (Table 4 ). The rate of phospholipid methylation expressed as a percentage of phospholipid radioactivity in phosphatidylcholine was decreased in vitamin $B_{12}$-deficient rats. The increase observed after injection of methionine was not significant. 


\section{DISCUSSION}

The depressed concentrations of folate found in vitamin $\mathrm{B}_{12}$-deficient hepatocytes (Table $\mathrm{I}$ ) are in accordance with observations in vivo (Smith \& Osborne-White, 1973; Thenen \& Stokstad, 1973), where rats were kept on vitamin $\mathrm{B}_{12}$-free diets also low in methionine. It has been demonstrated by Krebs et al. (1976) that hepatocytes may lose as much as $90 \%$ of their methionine content during cell preparation. Therefore, both the vitamin $\mathrm{B}_{12}$-deficiency and control hepatocytes might be depleted of methionine in analogy to the dietary studies cited above.

The most probable explanation of the depressed liver folate secondary to the vitamin $\mathrm{B}_{12}$-deficient is that the synthesis of polyglutamic folates is disturbed. (Buehring et al. 1972; Chiao \& Stokstad, 1977). These folates are the dominating forms intracellularly and tetrahydrofolic acid the preferred substrate in their synthesis (Lavoie et al. 1974; Chiao \& Stokstad, 1977). Furthermore, the synthesis of polyglutamic folate is a relatively slow process with maximal radioactivity $24 \mathrm{~h}$ after administration of labelled folate (Chiao \& Stokstad, 1977). In the presence of methionine, the uptake and retention of $\left[{ }^{3} \mathrm{H}\right]$ folic acid is greatly increased (Vidal \& Stokstad, 1974; Williams \& Spray, 1976; Chiao \& Stokstad, 1977), as was also demonstrated in vitro in the present study. This effect of methionine has been found to be associated with increased synthesis of polyglutamic folate. (Buehring et al. 1972; Chiao \& Stokstad, 1977).

The suggestion of a direct involvement of vitamin $B_{12}$ in the cellular uptake of folates has not received much support in recent studies (Shane et al. 1977; Horne \& Briggs, 1980). The vitamin $B_{12}$ state of the cultured hepatocytes in the present study did not affect the uptake and retention of exogenous labelled folate derivatives $\left(\left[{ }^{3} \mathrm{H}\right]\right.$ folic acid and $\left[5^{-14} \mathrm{C}\right]-$ methyltetrahydrofolic acid). This is not consistent with in vivo findings (Kutzbach et al. I967; Gawthorne \& Stokstad, 1971; Thenen \& Stokstad, 1973; Fehling \& Jägerstad, 1978), where vitamin $B_{12}$-deficient animals usually retain smaller amounts of exogenous labelled folate derivatives. One explanation for this discrepancy in the results of in vivo and in vitro experiments could be differences in the methionine concentrations with consequences on the formation of polyglutamic folates. Both vitamin $\mathbf{B}_{\mathbf{1 2}}$-deficient and supplemented in vitro hepatocytes may be more, and equally, depleted in methionine (Krebs et al. 1976) than livers of living rats. In vivo, control rats probably have higher tissue concentrations of methionine when compared with the vitamin $\mathbf{B}_{12}$-deficient animals because the vitamin $B_{12}$-dependent conversion of homocysteine to methionine may occur fully only in the control group (Fig. I).

According to the methyl folate trap theory (Noronha \& Silverman, 1962; Herbert \& Zalusky, 1962), 5-methyltetrahydrofolic acid accumulates during vitamin $\mathrm{B}_{12}$-deficiency. Such an accumulation of 5-methyltetrahydrofolic acid has been demonstrated in livers of vitamin $\mathrm{B}_{12}$-deficient rats when radioactivity from administered labelled folates have been studied (Buehring et al. 1972; Thenen \& Stokstad, 1973; Davidson et al. 1975). After equilibration of added labelled folate and the endogenous folate pool, microbiological assay of folate does not lend support to an intracellular accumulation of methylated folates in vitamin $\mathrm{B}_{12}$-deficiency (Davidson et al. 1975; Fehling \& Jägerstad, 1978). Neither could an accumulation of 5-methyltetrahydrofolic acid be shown in the cultured hepatocytes where methylated folate constituted approximately $50 \%$ of the total folate in the vitamin $\mathrm{B}_{12}$-deficient hepatocytes compared to $70 \%$ in the vitamin $\mathrm{B}_{12}$-supplemented cells.

The levels of 5-methyltetrahydrofolic acid appear to be controlled by two enzymes. The first one, 5, I0-methylenetetrahydrofolate reductase, catalyses the conversion of 5, 10-methyltetrahydrofolic acid to 5-methyltetrahydrofolic acid, and this conversion is most likely irreversible under physiological conditions (Katzen \& Buchanan, 1965). The second enzyme 


\section{Margaretha Jägerstad, B. Akesson and C. Fehling}

controlling the level of 5-methyltetrahydrofolic acid is the vitamin $B_{12}$-dependent 5-methyltetrahydrofolate:homocysteine methyltransferase (Fig. I). In vitamin $\mathbf{B}_{\mathbf{1 2}}$-deficiency this methyltransferase is depressed (Dickerman et al. 1964; Kutzbach et al. 1967), and consequently 5 -methyltetrahydrofolic acid should accumulate according to the methyl folate trap theory. A combined deprivation of vitamin $B_{12}$ and of methionine also should result in an accumulation of 5-methyltetrahydrofolic acid, because S-adenosylmethionine formed from methionine inhibits 5,10-methylenetetrahydrofolate reductase (Kutzbach \& Stokstad, I97I). Thus, in the absence of methionine, this inhibitory effect fails to appear.

Addition of methionine to the culture medium altered the proportions of 5-methyltetrahydrofolic acid, mainly because of an increase of methylated folate in the vitamin $\mathbf{B}_{12}$-deficient cells from 50 to $70 \%$, whereas non-methylated folate increased in the control cells altering the proportion of methylated folate from 70 to $60 \%$. These different effects of the methionine supply may seem inconsistent but are possible to explain on the basis of the methyl folate trap theory.

According to Fig. I the added methionine may be converted to S-adenosylmethionine. That S-adenosylmethionine actually is formed is supported by the enhanced methylation of phosphatidylethanolamine to phosphatidyl choline (Table 3). Consequently, the levels of S-adenosylhomocysteine may increase, too, and the inhibitory effect of S-adenosylmethionine on the 5, 10-methylenetetrahydrofolate reductase has been shown to be partially reversed by S-adenosylhomocysteine (Kutzbach \& Stokstad, 1971). Therefore, formation of 5-methyltetrahydrofolic acid is possible in the presence of methionine. In the presence of adequate amounts of vitamin $B_{12}$, as in the control group, a demethylation of methylated folates may rapidly occur resulting in a net increase of non-methylated folates, whereas a lack of vitamin $B_{12}$ could depress the demethylation by inhibition of methyltransferase resulting in an accumulation of 5-methyltetrahydrofolic acid (Fig. r).

A study performed in cultured bone marrow cells obtained from vitamin $B_{12}$-deficient rats reports similar effects of added methionine on the levels of methylated folate (Cheng et al. 1975).

The present study also confirms a previous report (Åkesson et al. 1978), where vitamin $B_{12}$-deficient rats were shown to have reduced ability to methylate phospholipids in their livers. This is consistent with a depressed activity of the vitamin $\mathbf{B}_{12}$-dependent methyltransferase reaction producing less methionine for methyl group transfer (Fig. I).

In the vitamin $\mathbf{B}_{12}$-depleted cultured hepatocytes, the phospholipids incorporated only approximately half of ${ }^{14} \mathrm{C}$-labelled methyl groups from $\left[5^{-14} \mathrm{C}\right]$ methyltetrahydrofolic acid as in the control hepatocytes. The addition of methionine increased this incorporation tenfold in both groups. In living animals, however, the effect of methionine was less pronounced (Table 4). The methionine concentration may be of great importance for this effect and was probably lower in the in vivo experiment.

The use of cultured hepatocytes is promising for further research to elucidate the complex relationship between methionine, vitamin $\mathbf{B}_{12}$ and folate metabolism. Several of the previous results obtained in vivo have been confirmed in the hepatocyte model used in the present study. On the other hand, divergent results here and in other studies may be due to unphysiologically high concentrations in the culture medium of the substances studied.

Ms K. Kvist, Ms B. Mårtensson and Mrs A-K. Westesson provided skilful technical assistance. This investigation was supported by grants from the Swedish Medical Research Council (projects 3968, 4343), the Faculty of Medicine, University of Lund and A. Påhlsson's Foundation. 


\section{REFERENCES}

Åkesson, B. (1977). Biochem. Biophys. Res. Commun. 76, 93.

Ákesson, B., Fehling, C. \& Jagerstad, M. (1978). Br. J. Nutr. 40, 52 I.

Åkesson, B., Fehling, C. \& Jăgerstad, M. (1979). Br. J. Nutr. 4I, 263.

Buehring, K. V., Batra, K. K. \& Stokstad, E. L. R. (I972). Biochem. biophys. Acta 279, 498.

Chanarin, I., Perry, J. \& Lumb, M. (1974). Lancet i, I 251 .

Cheng, F. W., Shane, B. \& Stokstad, E. L. R. (1975). Br. J. Haemat. 31, 323.

Chiao, F. \& Stokstad, E. L. R. (1977). Proc. Soc. exp. biol. Med. 155, 433.

Davidson, G., Weir, D. \& Scott, J. (1975). Biochem. biophys. Acta 392, 207.

Dickerman, H., Redfield, B. G., Bieri, J. G. \& Weissbach, H. (1964). J. Biol. Chem. 239, 2545.

Fehling, C. \& Jägerstad, M. (1978). Nutr. Metab. 22, 90.

Fehling, C., Jägerstad, M., Âkesson, B., Axelsson, J. \& Brun, A. (1978). Br. J. Nutr. 39, 501.

Gawthorne, J. M. \& Stokstad, E. L. R. (1971). Proc. Soc. exp. biol. Med. 136, 42.

Herbert, V. \& Das, K. C. (1976). Vitams. Horm. 34, 1.

Herbert, V. \& Zalusky, R. (1961). Clin. Res. 9, 16I.

Herbert, V. \& Zalusky, R. (1962). J. clin. Invest. 4I, I 263.

Horne, D. W. \& Briggs, W. T. (1980). J. Nutr. 1ro, 223.

Katzen, H. M. \& Buchanan, J. M. (1965). J. biol. Chem. 240, 825.

Krebs, H. A., Hems, R. \& Tyler, B. (1976). Biochem. J. 158, 34 I.

Kutzbach, C., Galloway, E. \& Stokstad, E. L. R. (1967). Proc. Soc. exp. biol. Med. 124, 801.

Kutzbach, C. \& Stokstad, E. L. R. (I 97I). Biochem. biophys. Acta 250, 459.

Lavoie, A., Tripp, E. \& Hoffbrand, A. V. (1974). Clin. Sci. Mol. Med. 47, 617.

Lin, R. C. \& Snodgrass, P. J. (1975). Biochem. Biophys. Res. Commun. 64, 725.

Noronha, J. M. \& Silverman, M. (1962). In Vitamin $B_{12}$ and Intrinsic Factor, p. 728 [H. C. Heinrich, editor].

Hamburg. Stuttgart: Enke.

Shane, B., Watson, J. E. \& Stokstad, E. L. R. (1977). Biochem. biophys. Acta 497, 241.

Smith, R. M. \& Osborne-White, W. S. (1973). Biochem. J. 136, 279.

Thenen, S. W. \& Stokstad, E. L. R. (1973). J. Nutr. 103, 363.

Vidal, A. J. \& Stokstad, E. L. R. (1974). Biochem. biophys. Acta 362, 245.

Williams, D. L. \& Spray, G. H. (1976). Br. J. Nutr. 35, 299. 